\title{
Collecting, Organizing, and Teaching the Ephemera of Art Biennials
}

\author{
Alexander Watkins, University of Colorado Boulder \\ Jane Thaler, University of Colorado Boulder
}

\begin{abstract}
Art fairs and biennials have become an essential part of the story of contemporary art and architecture. Ephemeral handouts, pamphlets, and posters—a hallmark of these gatherings - have the potential to help students and researchers understand these events if preserved for future use. However, libraries and archives that want to collect ephemeral material from biennials face several challenges, including the difficulty of collecting these materials remotely, developing appropriate methods to best organize this type of material, and determining the best way to present these materials to students and scholars. This article describes a case study at the University of Colorado Boulder of creating an archival collection of ephemera from biennials.
\end{abstract}

\section{INTRODUCTION}

At each pavilion of the 2016 Venice Architectural Biennial, there were books, explanatory sheets, postcards, brochures, and the occasional bag of rocks (Figures I, 2, and 3). This ephemeral material is an integral part of the diverse creative fabric of art biennials. Reporting from the Front, the 2016 Venice Architectural Biennial, sought to explore architecture that confronts society's most pressing problems and to improve international living conditions. To kick off the main exhibit, curator Alejandro Averna built an installation entirely from the waste material of the recently disassembled Venice Art Biennial of 20I5. Waste, trash, and recycling were referenced repeatedly and considered through the thematic elements of the international pavilions and by the works chosen for the main exhibit. Especially in light of these ideas, one is encouraged to

Alexander Watkins is art and architecture librarian, University of Colorado Boulder, Boulder, Colorado; alexander. watkins@colorado.edu. Jane Thaler is project archivist, University of Colorado Boulder, Boulder, Colorado; jane.thaler@ colorado.edu.

Art Documentation: Journal of the Art Libraries Society of North America, vol. 37 (spring 2018)

0730-7187/2018/3701-0006 \$10.00. (c) 2018 by The Art Libraries Society of North America. All rights reserved. 


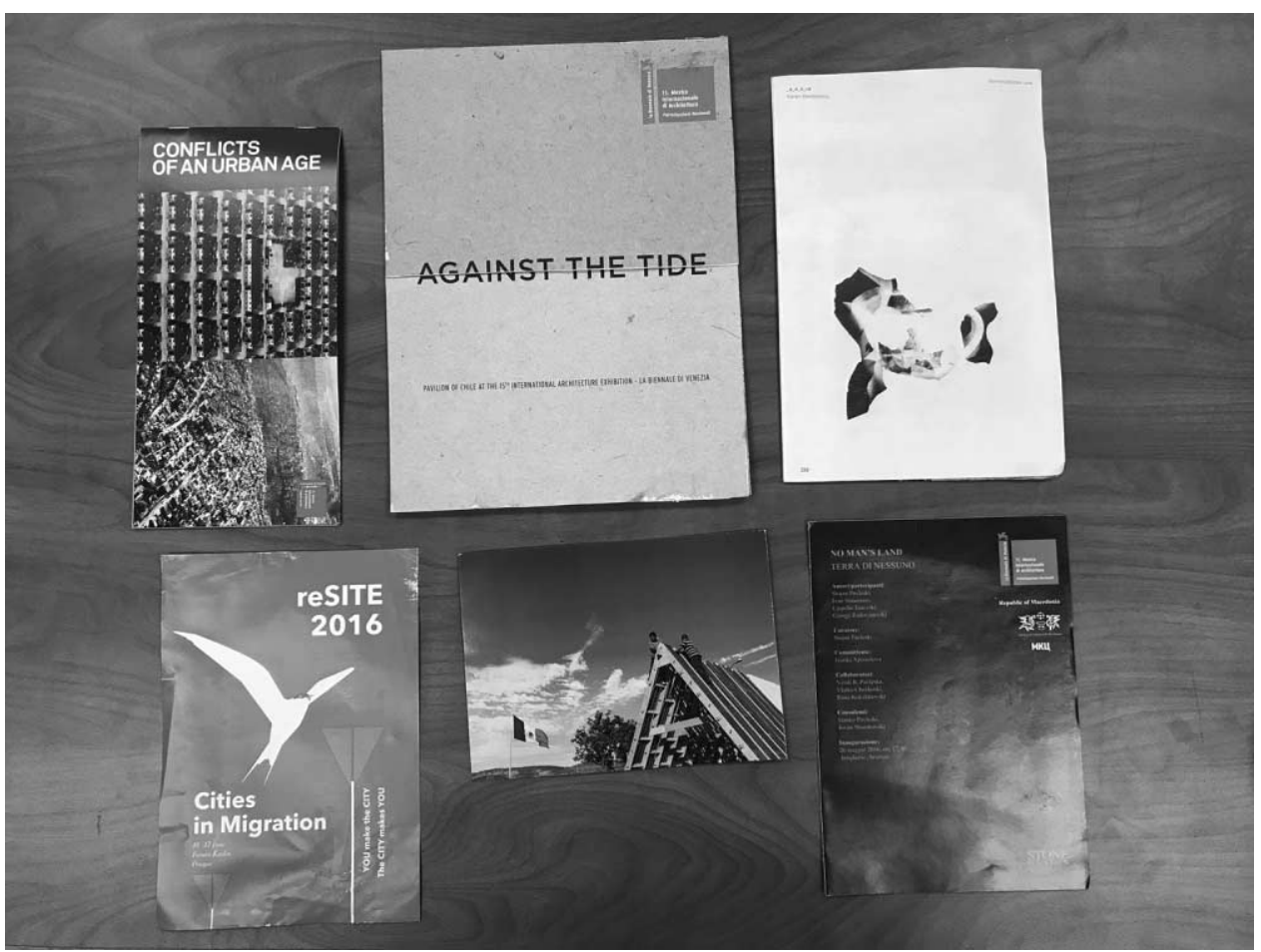

Figure 1. Pamphlets from the 2016 Venice Architectural Biennial. Photograph by Alexander Watkins. Please see the online edition of Art Documentation for a color version of this image.

examine the fate of the ephemeral materials created and disseminated at these events. Is the seemingly mountainous quantity of ephemera that biennials produce being preserved and used? What is the life of this material? Is it doomed to sit in the tote bags of attendees, never to be looked at again? This article examines how libraries and archives collect, organize, and use this material, drawing on the University of Colorado Boulder (CU Boulder) collection as a case study. The authors' goal is that these materials not go to waste, but rather become instrumental in the documentation, study, and teaching of such events.

\section{THE IMPORTANT ROLE OF BIENNIALEPHEMERA}

ART BIENNIALS

Biennials and art fairs have proliferated over the last thirty years, shifting the center of gravity in the art world and creating a biennial art culture that seems to relentlessly "pursu[e] the production of new experiential worlds." Biennials, as their name implies, are art exhibits held every two years, most often showcasing contemporary art. The Venice Art Biennial is widely considered to have originated this formula in

I. Caroline A. Jones, The Global Work of Art: World's Fairs, Biennials, and the Aesthetics of Experience (The University of Chicago Press, 2016), 203. 


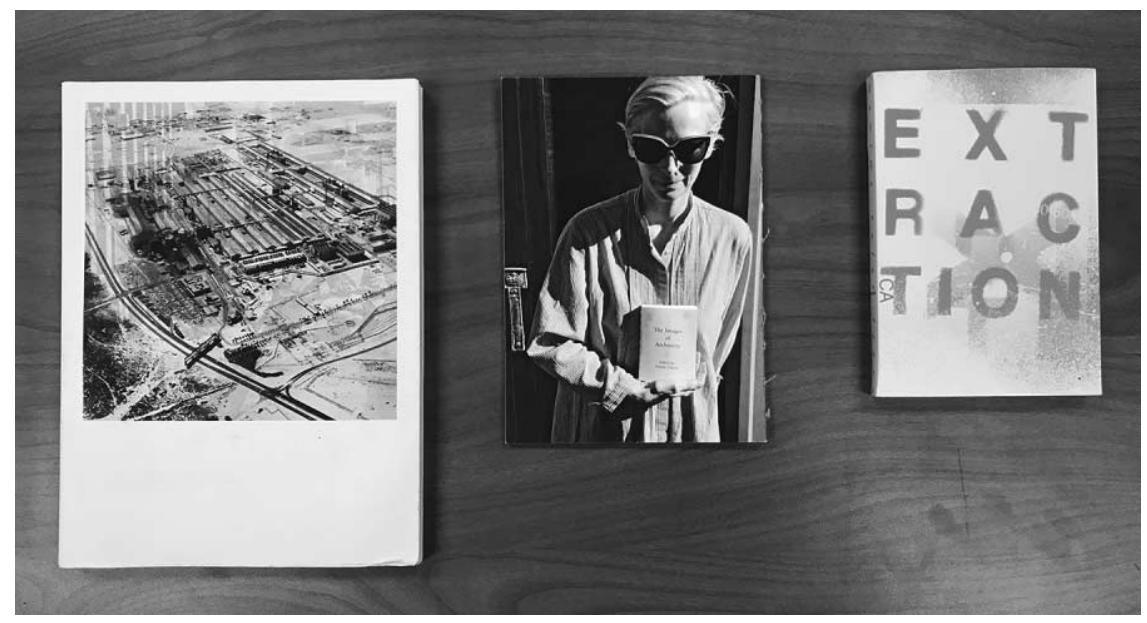

Figure 2. Book-length ephemera from the 2016 Venice Architectural Biennial. Photograph by Alexander Watkins. Please see the online edition of Art Documentation for a color version of this image.

I895 and has since risen to become the preeminent contemporary art event in the world. It includes multiple "pavilions," separate buildings reserved for the art of particular countries. The Venice Architectural Biennial began as an offshoot of the art biennial in I980 and continued the tradition of using country-based pavilions. During the I980s and I990s a process of "biennalization" began to accelerate, and there are now over a hundred biennials held regularly. ${ }^{2}$ Increasingly, the history of twenty-first century art is told through these art events. Biennials are important not only as gatherings that reflect the art world but also as a type of aesthetic experience in themselves. These events encapsulate the art world in a way that is more complete and more complex than in other institutional settings, standing in contrast to more tightly controlled museum exhibitions. ${ }^{3}$ Though these events often have lead curators and overarching themes, they are, in practice, a mélange of the ideas of various curators, artists, and institutions that converge at and participate in the event. This intersection of perspectives makes archiving and collecting a broad array of materials, such as ephemera that can speak in the words and images of participants, especially important.

\section{ARCHIVES AND TRANSITORYART EVENTS AND EXPERIENCES}

As the recycling and reuse of the 2015 Venice Art Biennial materials as a standalone exhibit in the 2016 biennial makes clear, much of the production of biennials is thrown away. This practice is increasingly untenable not only environmentally, but also historically, as these events are recognized as having a key role in art and architecture history. Acknowledging the importance of these events, many academic libraries

\footnotetext{
2. Gustavo Grandal Montero, "Biennalization? What Biennalization? The Documentation of Biennials and Other Recurrent Exhibitions," Art Libraries Journal 37, no. I (January 20I2): I3.

3. Francesco Garutti et al., eds., Fairland: Explorations, Insights and Outlooks on the Future of Art Fairs (London: Koenig Books, 20I4).
} 


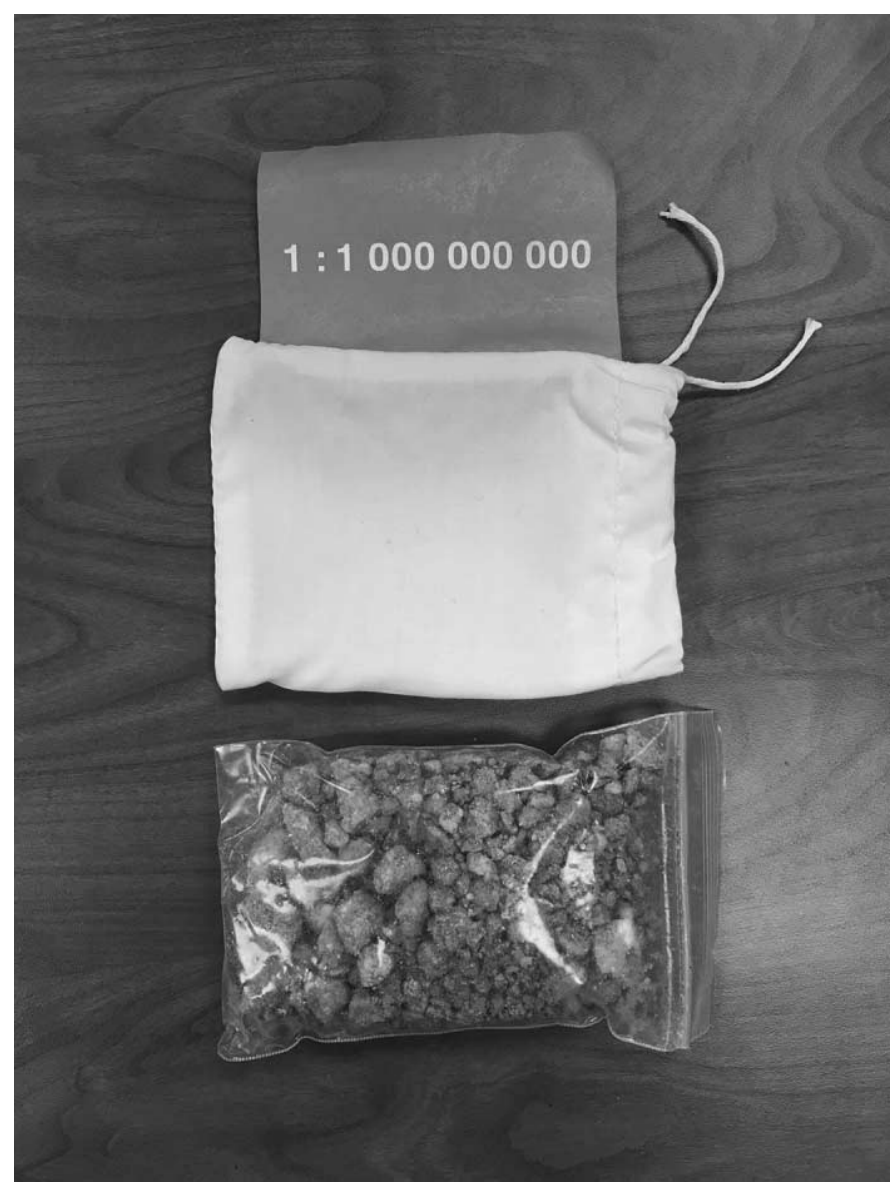

Figure 3. 1:100000000, ephemeral artwork distributed at the Canadian Pavilion exhibit "EXTRACTION" during the 2016 Venice Architectural Biennial. Photograph by Alexander Watkins. Please see the online edition of Art Documentation for a color version of this image.

collect the exhibition catalogs that document the biennials, but these publications highlight only the core works selected by the curators and do not capture the nuance and texture of these events. The biennials are important not only because of the official activities, but also because of the unsanctioned counter-events and artistic protests that accompany major biennials that official catalogs do not capture. Jacqueline Cooke has demonstrated persuasively the importance of art ephemera in documenting alternative art movements. ${ }^{4}$

Biennials are transitory and ephemeral art events, and they should be considered alongside other aesthetic experiences such as performance art, intervention, social practice, and additional non-objective work. As Caroline A. Jones argues, biennials

4. Jacqueline Cooke, "Heterotopia: Art Ephemera, Libraries, and Alternative Space," Art Documentation 25, no. 2 (Fall 2006): 34-39. 
continue a movement towards an "aesthetics of experience" that started with performance, land art, and art scores. ${ }^{5}$ Biennials, performance, and other kinds of experiential art are stored primarily in the sensory memories of the participants. Though biennials and other art events often have a prescribed duration, their effects last as "the work continues through oral accounts that are passed-on, rumours, hearsay." ${ }^{6}$ Artist Kira O'Reilly describes her performance as continuing "in its remains, memories and objects ... The stories the guests may or may not have told after the event; private anecdotal accounts they might have felt moved to speak." 7 These aesthetic experiences have a longer tail than is suggested by their limited duration, shared out to communities through participants who transport the idea of the work in their body. ${ }^{8}$ This transmission through body, memory, story, and shared experience challenges the document as the only acceptable means of transmitting knowledge. ${ }^{9}$

Because of their transitory nature and academic focus on written documentation, these events are often represented and studied through surrogates such as photos, videos, and exhibition catalogs. As these images often become so associated with the events they represent, there is a strong tendency for particularly iconic images of a performance to supplant the performance act itself. ${ }^{\text {IO }}$ Biennials face a similar risk, as a single exhibition catalog can reduce a complex and multi-dimensional event to a single curated story. The collection of documentation and its intellectual organization in libraries and archives can help evoke the multifaceted nature of these complex events by bringing together images, video, artifacts, and ephemera. This can counteract the tendency for one surrogate to replace the now disappeared original event because a critical mass of documentation can prevent distortion and elision. ${ }^{\text {II }}$

SCHOLARSHIP AND BIENNIAL EPHEMERA

Ephemeral materials are critical to the art historical scholarship of biennials. Without an art object to study, art researchers will rely on the archival documentation to understand the aesthetic experience of participants. Art historian Amelia Jones candidly discusses her research on art events that she has not seen, and her main difficulty is in locating the necessary documentation. ${ }^{\mathrm{I}}$ Art researchers need visual forms of documentation that reflect the visual landscape of the art event. Ephemeral works with their visual design and material connection to the art event are one important piece of this

5. Jones, The Global Work of Art, I98.

6. Paul Clarke and Julian Warren, "Ephemera: Between Archival Objects and Events," Journal of the Society of Archivists 30, no. I (April I, 2009): 50, https://doi.org/I0.1080/003798109032646r7.

7. Adrian Heathfield, Small Acts: Performance, the Millennium and the Marking of Time (London: Black Dog Publishing, 2002), 120.

8. Jones, The Global Work of Art, 201.

9. Rebecca Schneider, "Performance Remains," Performance Research 6, no. 2 (January 200I): IOI, https://doi.org/ı .I080/13528165.200I.10871792.

Io. Amelia Jones, "Presence' in Absentia: Experiencing Performance as Documentation," Art Journal 56, no. 4 (Winter 1997): II-I8, https://doi.org/I0.2307/777715.

II. Christina Manzella and Alexander Watkins, "Performance Anxiety: Performance Art in Twenty-First Century Catalogs and Archives," Art Documentation 30, no. I (Spring 20II): 28-32.

I2. Jones, "'Presence' in Absentia." 
puzzle. Gustavo Grandal Montero speculates that the relative scarcity of this kind of primary source material from biennials has resulted in more limited literature and scholarship despite significant interest in the subject. ${ }^{\mathrm{I} 3}$ Collecting ephemera is one way that libraries can enrich their documentation of biennials and enable researchers to study these events. However, much of the collection development around ephemera has been conducted passively as this material is traditionally sent unsolicited to art libraries. ${ }^{14}$ Montero's important article on collecting biennial materials has begun to change this mindset in libraries, opening the doors for a more proactive approach to biennial ephemera. ${ }^{15}$

\section{VENICE BIEN NIAL EPHEMERA AT UNIVERSITY OF COLORADO BOULDER}

COLLECTING BIENNIALEPHEMERA

At the University of Colorado Boulder, the library has a collection of ephemera from several Venice Architectural Biennials that is part of the Post-Studio Art Collection. The collection's frequent use in instruction has proven its value but has also exposed the challenges of acquisition and organization. Initially, the collection was formed by a few items from a faculty member's work exhibited as part of the show at the US pavilion during the 2012 Venice Architectural Biennial. Materials from other creatives involved in the biennial were then gathered by sending a solicitation email to all of the participants in the US pavilion exhibition. Many donated their materials, which included books, postcards, posters, and even t-shirts. The collection was expanded in 20I6, when one of the authors (Watkins) traveled to the 2016 Venice Architectural Biennial to collect materials and to visit the Venice Biennial archive.

In many ways, the Venice Biennial is an outlier, as it has its own archive, the Archivio Storico di Arte Contemporanee (ASAC), which actively collects a variety of materials from the art and architecture biennials. The biennial poses a significant collecting challenge with two main locations and pavilions for sixty-nine countries located throughout the city, along with many collateral events dotted around Venice. Because of the individualized mini-exhibit nature of each of these pavilions and events, each one often has its own set of ephemera, which the archivists at ASAC carefully attempt to collect. This requires attendance at press previews, where the extremely useful press packets are available, but also at least one more sweep through the exhibition to find items that were not available at the preview. ${ }^{16}$ This second trip needs to be made early as only a limited number of the pavilion-specific documents are created, and they can run out. However, even this degree of vigilance does not secure all of the biennial's ephemera. The author compared CU Boulder's collection against what had been col-

\footnotetext{
I3. Montero, "Biennalization? What Biennalization?," I6.

I4. Frédéric Casiot, "The Collection of Ephemera at the Bibliothèque Forney in Paris," Art Libraries Journal 3I, no. 4 (October 2006): 2I-26; Elizabeth Lawes and Vicky Webb, "Ephemera in the Art Library," Art Libraries Journal 28, no. 2 (2003): 35-39; Chris E. Makepeace, Ephemera: A Book on Its Collection, Conservation, and Use (Aldershot, UK: Gower, I985).

I5. Montero, "Biennalization? What Biennalization?"

I6. Gallina Marcina, Archivio Storico di Arte Contemporanee (ASAC), interview by Alexander Watkins, May 3I, 20 I6.
} 
lected by ASAC and found ASAC's collection to be more limited. The Venice Biennial is divided between a main exhibit (with a single curator who selects participants) and the national pavilions. ASAC collects only the official ephemera given out for the main exhibition as a whole, not that of its numerous individual artworks and installations, many of which had their own ephemera. At the 2016 Biennial, Watkins was able to gather a large amount of ephemera from individual installations at the main exhibit at the Arsenale that was not represented in ASAC's archive. It was also possible to collect ephemera from abroad that ASAC had missed. From the United States architecture pavilion in 20I2, ASAC had only a few flyers that described the program of the pavilion generally. In reality, this exhibit was made up of many architects and artists engaging in artistic and architectural interventions who each had their own array of ephemera. To obtain these materials for the Post-Studio Art Collection, CU Boulder contacted the participants through email solicitation after the event had already happened. In this manner, the authors obtained ephemera that the ASAC had not collected. On the other hand, even though the participants sent materials related to the biennial, it is not clear how much of this material was originally given out at the biennial, which could give a distorted view of the event. Even though the Venice Biennial has its own impressive archives, it seems there is always more ephemera to collect.

While it is clear that attendance at a biennial can create the most representative collection of biennial ephemera, this approach is labor- and cost-intensive. Gathering materials at a distance is a good option when a visit is not possible. However, that method makes it harder to ensure an accurate picture of the biennial's aesthetic experience. The collection and preservation of this material at biennials other than Venice may be even more essential. Many, such as Manifesta, have no active archival program and no paid archivists. Their archival collections consist primarily of their own internally produced records. ${ }^{17}$ Unfortunately, this means that potentially rich sources of information are being lost.

ORGANIZING BIENNIAL EPHEMERA

It is a challenge to organize this potential avalanche of materials to provide access while also upholding preservation standards. At ASAC, the ephemeral materials are organized by biennial and then by pavilion. The items are placed in binder sleeves, and each piece is recorded and cataloged in an inventory list. Larger items are stored separately but also noted in the inventory list. This organizational system allows a researcher to see all the ephemera from a particular biennial and from each pavilion. This method differs from how typical art ephemera collections are organized, usually being sorted by artist or gallery. Dividing biennial ephemera into individual artists' files risks losing the overall context of the event, which is important to the historical record in its own right. At the 2016 Venice Architectural Biennial, clear themes and preoccupations surfaced repeatedly. Viewed together, the ephemeral materials clearly demonstrate the zeitgeist of this event and reflect the state of architectural thinking at the time.

I7. Manifesta Biennial, email conversation on Manifesta Biennial Archives with Alexander Watkins, April 2016. 
When determining the arrangement and description of the Post-Studio Art Collection at CU Boulder, it became clear that the materials needed to be processed to document their relationships to one another and their place in the biennial as a whole. The goal is to give scholars a fuller and more accurate impression of the entire event. The authors decided to use an archival instead of an artists'-files approach to maintain the contextual indicators that provide researchers with more clues than might be present by simply looking piece by piece at the content. Archival organization recognizes that it is difficult to understand individual records without also understanding the historical, legal, procedural, and documentary context from which those records were born. ${ }^{18}$ Of course, use of such an organizational system depends on the goals of the collection, as organizing these items by individual artists would have other benefits for researchers, such as increased discoverability when browsing or searching by artist. The authors found when preserving the context of a time-limited event where each creator made work that relates very directly to an overarching theme designated by the biennial curators that using a style similar to that of the ASAC preserved the most relevant contextual information.

In this case, the materials were meant to be used for teaching, made available to public researchers, and housed for preservation in the archives. In addition, the collection needed to be easy to expand as more materials are collected. This led to a mixture of processing approaches wherein the authors decided to group the materials intellectually into series according to project or exhibition in a style similar to that of the ASAC, physically house according to both intellectual grouping and size, then describe the materials within these series in various ways depending on the materials in a given series. For example, every item in a series includes a title, creator (person, corporation, etc.), and date, but some also include curator or location information. Recording creators in the finding aid allows the collection to be searchable by artist or architect.

Once the materials in a series were sorted, rehoused, and described in a finding aid, the authors used the Scope and Content section of the same finding aid to write brief background paragraphs concerning the projects or exhibitions with a note identifying which items are included in the collection. The authors sought to create a finding aid that was not overly detailed but still informative enough to give both students and teachers the background information needed to determine what might be useful to them. While this information is usually divided into Biography/History and Scope and Content, the authors chose to combine the two for ease of contextual access between the two styles of information.

The preservation of contextual information as its own form of evidence can provide insight into the processes, activities, and events that led to the materials' creation. ${ }^{19}$ Once broken up, the "integrity of evidential value" ${ }^{20}$ is lost, and it would be

I8. Anne Gilliland-Swetland, "The Archival Paradigm: The Genesis and Rationales of Archival Principles and Practices," in Enduring Paradigm, New Opportunities: The Value of the Archival Perspective in the Digitial Environment (Washington, DC:

Council on Library and Information Resources, 2010), I8.

I9. Gilliland-Swetland, Io.

20. "The integrity of the evidential value of materials is ensured by demonstrating an unbroken chain of custody, precisely documenting the aggregation of archival materials as received from their creator and integrated with the rest of the 
difficult to recreate this connection. ${ }^{21}$ Keeping this material grouped in terms of its original dissemination point allows researchers to get a fuller picture of the nature of this event through contextual clues. The study of experiential art events can be enriched by organizing ephemera in this way because, as Jessica Santone argues, "each document touches at its root the idea of the original, and then moves out from there, diverging in various ways, connecting to other documents, and producing an accumulation that is best understood collectively." ${ }^{22}$

TEACHING WITH BIENNIAL EPHEMERA

The collection of biennial ephemera was assembled in part as an aid for instruction and teaching. Several uses for ephemera in instruction have been explored in the literature. Jennifer Garland explains how ephemera can be used to teach visual literacy by having students find, use, and interpret visual primary source material. ${ }^{23}$ Julia Gardner and David Pavelich compare the use of ephemera with the standbys of special collection classes: Dante, Cervantes, and Copernicus. They argue that ephemera can add to the appreciation of historical nuance and humanize historical events. ${ }^{24}$ The authors have found that ephemera can do much the same for biennials, adding nuance to and humanizing these well-known and in some cases glamourized events. This makes ephemera an excellent resource when teaching the history of exhibitions, biennials, and global contemporary art. The collection gives students a more concrete idea of the reality of art biennials. Using ephemera in this way can be challenging because often the librarians will not have attended the event themselves. Teaching in this situation relies on the organization of the materials to help the instructor tell the stories of these biennials and to provide context for the items that are being shown. By maintaining links and contexts, the organization of the ephemera can help students and teachers see connections that may not be apparent if the materials are separated or dispersed.

The CU Boulder ephemera collection is especially useful for classes designed for art practice students. The authors use the ephemera collection extensively in sessions with the Sculpture and Post-Studio Practice classes that "explore the development of participatory and object-based works, ephemeral activities, public and installation art, and socially engaged, collaborative and site-specific approaches." ${ }^{25}$ Understandably, the authors have found that students often have difficulty imagining what they might display after such ephemeral art works have ended. Biennial ephemera are

\footnotetext{
archives' holdings of the same provenance, and tracking all preservation activities associated with the materials." Gilliland-Swetland, Io. 2I. Gilliland-Swetland, Io. 
excellent examples of the ways artists and architects document, present, and explain their work, helping students concretize what such accompanying material might look like. The materials demonstrate to students what they might create to supplement their performance, ephemeral, and interventionist projects that might otherwise have no lasting physical presence. The authors use the ephemera to inspire students to think critically about the documentation of their own work and how they might choose to disseminate information about their art.

These ephemeral materials can also teach students about visual communication and activist thinking in art. Much of the ephemera from the Venice Architectural Biennial has an activist tilt, such as a fold-out poster explaining how to revive empty lots. In these cases the ephemeral materials are a key part of the art piece, and their dissemination is one of the important ways the art communicates. Ephemera can illustrate ways that art and its documentation can work to affect change. Having concrete examples of how other artists have created such documents can help students combine ephemera with their art practice to broadly communicate and educate.

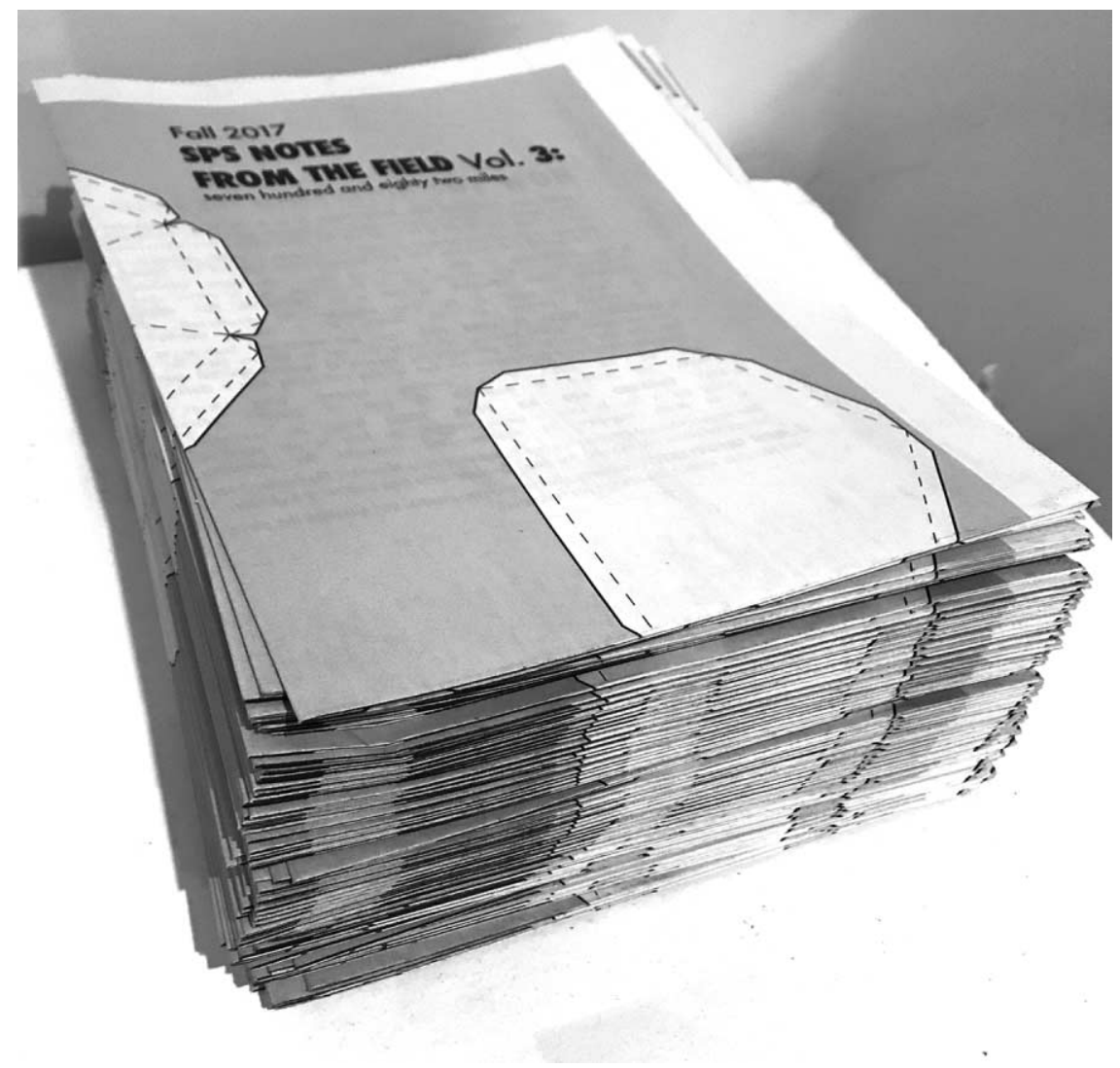

Figure 4. Ephemeral publication created by University of Colorado Boulder graduate art students, documenting their work and the ephemera exhibition. Photograph by Alexander Watkins. 
Currently the authors are working with a graduate art class to create an exhibit of items drawn from the collection alongside response works made by the students. The students came in for an initial class in the archives reading room to view and engage with the materials. Students shared objects they found particularly interesting with the rest of the class. In a second session that focused on research skills, students used collaborative mind-mapping to explore possible themes for the exhibit. They also learned skills for researching their chosen themes. Students went away with the finding aid to the collection, and then made individual appointments to look at the items to which they wanted to respond. Students then installed their work and arranged the display of the ephemeral materials. Inspired by the post-studio collection, students created their own ephemeral publication documenting their work and the show, which is available for visitors to take (Figure 4). This amount of engagement with a single class is the exception, but it demonstrates that ephemera can inspire artists directly to create their own works.

\section{CONCLUSION}

Preserving ephemera enables future understandings and analyses of biennials. Libraries, even those far away from the biennials themselves, can help collect this material that so often slips through the cracks. Together, libraries can build the critical mass of evidence that allows these events to be understood more thoroughly and prevents them from being reduced to a single iconic piece of documentation. By treating this material as a cohesive collection instead of separate works, libraries maintain context that can help researchers and teachers piece together the aesthetic experience of an event. This material should not go to waste-it is too valuable a teaching tool for emerging artists, inspiring them to create new experiential art works that will be preserved both through the memories of participants and in collections of ephemera.

\section{ACK NOWLEDGM ENTS}

This article was made possible by the H.W. Wilson Foundation Research Award, which funded travel to the Archivio Storico delle Arti Contemporanee and the 2016 Venice Architectural Biennial. 